\title{
ANALYSIS OF PHOTOBIOLOGICAL PROCESSES AND INDICATORS OF PHOTOBIOLOGICAL SAFETY OF RADIATION SOURCE OF LIGHT
}

\author{
O. S. Pitiakov \\ O. M. Beketov National University of Urban Economy \\ Kharkiv, Ukraine
}

\begin{abstract}
Annotation - It was established that photobiological processes that arise under the influence of optical radiation cause photochemical and thermal reactions in organisms. Such reactions are directly related to the absorption of light from natural and artificial sources of radiation. It is established that the depth of penetration of optical radiation depends on the wavelength. Radiation of "blue light" is the most dangerous for the harmful effect on the retina and affects melanopsin cells. Also, in the visible area of the spectrum of artificial light sources, which are used for a long time in the evening and night periods, there can be dangerous "green light" as it is able to break the circadian rhythm and create a hormonal imbalance. Thus, the prolonged action of ultraviolet, visible and infrared radiation on the eyes and skin can cause a gene mutation, burns, disease and changes in the circadian rhythm. The article analyzes and systematizes the possible consequences and damage that may result from such an effect of optical radiation.
\end{abstract}

Ключові слова- optical radiation, photobiological safety, lamp, lamp system, exposition.

\section{INTRODUCTION}

The widespread use of LEDs in various areas of lighting technology faces a number of tasks for scientists to study, record and measure photobiotic radiation patterns. In Ukraine, the discussion of this issue in scientific circles has been taking place for some time, but the methods of recording photobiological indicators are not sufficiently worked out, and most importantly, when designing lighting equipment for LED lighting, the parameters of photobiological safety of radiation of lamps and lamp systems are not taken into account at all. Therefore, the development of general techniques and the creation of laboratory plants for the study of photobiological characteristics of radiation sources of light is an urgent task. In some countries, similar installations have already been established and relevant studies have been carried out. The purpose of this publication is to analyze and systematize the results and the main and determinants of photobiological effects and photobiological safety arising from the optical radiation of light sources, as well as the features of their calculation and the accounting of their indicators.

\section{THE ANALYSIS OF RECENT RESEARCH AND PUBLICATIONS}

The current pace of the development and implementation of LED technology in everyday life requires review of existing requirements and standards for their photobiological safety. This problem is raised by scientists from different fields of science.

The scientific-theoretical and normative basis of research and accounting of photobiological indicators of radiation of solid-state light sources does not fully meet the requirements of the present. This is evidenced by the research and publication of both domestic and foreign scientists. In particular, the problems of photobiological action and photobiotic safety of radiation of light sources were studied by L. Udovichich, F. Mainoush, M. Jansen, D. Novak, G. Ott, V. Holbritter, V. Horak, V. Yordan, D. Sliney, T. Okunov, G. Kozhushko, V. Kaptsov, E. Shutter and others.

We will consider the research of the scholarsmore detailed in the subsequent presentation of the article.

\section{PRESENTING THE MAIN MATERIAL}

Photobiological processes occurring in the body. Photobiological processes that cause certain photochemical reactions in organisms are directly related to the absorption of light from natural and artificial sources of radiation. Any photobiological process begins with the absorption of light quanta by biological functional molecules and ends with physiological reactions in the body and tissues. The effect of optical radiation on a person is limited to the perception of light by the eyes and the skin, and the depth of penetration at the same time depends on the wavelength. The perception of light with the eye is accompanied by the conversion of light energy into the energy of nerve impulses, and the perception of light by the skin is accompanied by a change in its condition and causes erythema, edema, tan, pigmentation, burn and even skin cancer.

The influence of optical radiation can be described by thermal and photochemical effects [1]. Thermal effects occur, as a rule, in the long-wavelength region 
of the visible spectrum and in the infrared region: the molecules in the tissue cause vibrations, which leads to the heating of the tissues. The heat that occurs in this case is transferred to the surrounding tissue. Due to increased local temperatures, damage to these tissues may occur. In photochemical processes, the energy of incident optical radiation is transformed not into heat but into the energy of the chemical reaction. These effects are generated by the energy of the photons, especially in the visible spectral range and in the ultraviolet (UV) radiation. Some biological molecules absorb falling optical radiation, and, excited, release their energy into an oxygen molecule. This creates a reactive oxygen formula (singlet oxygen). It binds to the surrounding tissues and generates free radicals that have high reactivity with molecules of surrounding cells, such as proteins or the genetic material of deoxyribonucleic acid (DNA), which can lead to their damage. Optical radiation, even in the short-wave UV spectral range, has sufficient photon energy for direct DNA damage by splitting the chemical bonds and, accordingly, can destroy various DNA structures. Such a DNA damage can be carcinogenic. As a result, compulsory biological reactions, so-called "phototoxic" reactions may occur.

The most vulnerable to damage from optical radiation is the human eye. Optical radiation passes through the cornea, the lens of the eye (lens) and the vitreous body, then reflected on the retina and may cause damage. Damage to the retina is particularly dangerous and leads to significant visual impairment. Damaged areas of the retina cause defects in the visual field, deterioration of sharpness and color vision. And if damaged blind spots in general, there may be complete blindness. It is also worth noting that the optical radiation in the infrared and ultraviolet spectrum also focuses on the lens on the retina, but since it does not have receptors that perceive this radiation, a person can not feel it. Although such radiation can cause damage that will be irreversible.

Thermal damage to the retina occurs when the temperature exceeds $10^{\circ} \mathrm{C}-20^{\circ} \mathrm{C}$ by the pigment epithelium of the retina from body temperature due to absorption of optical radiation [2]. Such damage to the retina occurs with a short exposure to radiation (less than $10 \mathrm{~s}$ ), and damage to the retina immediately begins to be felt. Thermal damage to the retina is mainly due to laser radiation. Photochemical damage to the retina (photoretinitis) occurs during a longer period of radiation (more than 10 seconds).

Ultraviolet and long-wave radiation is absorbed by the cornea, conjunctiva and lens, so these eye areas are most at risk. UV radiation can cause photochemical reactions that lead to corneal inflammation (photoceratitis) and / or conjunctiva (photo conjunctivitis). External cells of the cornea and conjunctiva are destroyed. Damage becomes noticeable within 4-12 hours after exposure to the eye. Since all epithelial cells are reproduced in the cornea and conjunctiva, this damage is reversible. Recovery usually takes a few days. Prolonged exposure to ultraviolet radiation of low intensity leads to acute corneal or conjunctival damage and can cause cataracts. Photochemical reactions in pupillary cells alter the structure of proteins (crystalline), which leads to pigmentation of cells. Cells in the eye lens do not play, so its damage is irreversible. As a rule, such damage occurs with long-term exposure to radiation. For example, the prolonged action of infrared radiation may cause clouding of the lens, which is formed by the condensation of its proteins. As T. Okun notes, the temperature of the lens, at which there can be a thermal cataract, is from $40^{\circ} \mathrm{C}$ to $45^{\circ} \mathrm{C}$ [3]. Such damage is irreversible, it leads to complete blindness, but it is treated surgically.

The depth of penetration of optical radiation into the skin, as well as in the eye, also depends on the wavelength. Most of the optical radiation in the range of the UV spectrum is absorbed by the epidermis, and the radiation in the visible and especially in the infrared region penetrates much deeper. Although long-wave infrared radiation is also absorbed by the epidermis. Chronic lesion with ultraviolet light leads to premature aging of the skin, causes temporary changes in its pigmentation and erythema. Also, the prolonged action of ultraviolet radiation on the skin can cause a gene mutation and lead to skin cancer. Intense radiation in the visible spectral range can lead to warming of the skin and cause photosensitive reactions, and the effect of intense infrared radiation can cause burns.

Summarizing information on the effects and damage caused by the effects of optical radiation on the eyes and skin of a person based on research results [4] on the radiation exposure of light emitting diodes performed by German scientists L. Udovichichem, F. Mainous, M. Jansen, D. Novak and G. Otto is given in Table 1.

TABLE I. POSSIBLE CONSEQUENCES AND DAMAGE FROM THE EFFECTS OF OPTICAL RADIATION ON THE EYES AND SKIN

\begin{tabular}{|c|c|c|}
\hline Spectrum range & Eyes & Skin \\
\hline $\begin{array}{l}\text { Short-wave ultraviolet } \\
(100-280 \mathrm{~nm})\end{array}$ & $\begin{array}{c}\text { Photoretite, } \\
\text { photoconjunctivitis }\end{array}$ & $\begin{array}{l}\text { Erythema, } \\
\text { skin cancer }\end{array}$ \\
\hline $\begin{array}{l}\text { Medium length wave } \\
\text { ultraviolet } \quad(280-315 \\
\mathrm{nm})\end{array}$ & $\begin{array}{c}\text { Photocerat, } \\
\text { photoconjunctivitis } \\
\text { cataract }\end{array}$ & $\begin{array}{c}\text { erythema } \\
\text { intensified } \\
\text { pigmentation } \\
\text { (pigmentation } \\
\text { of aging), } \\
\text { accelerated } \\
\text { processes } \\
\text { aging skin } \\
\text { skin cancer }\end{array}$ \\
\hline $\begin{array}{l}\text { Long length wave } \\
\text { ultraviolet } \\
(315-400 \mathrm{~nm})\end{array}$ & cataract & $\begin{array}{c}\tan \\
\text { (rapid } \\
\text { pigmentation) } \\
\text { accelerated } \\
\text { processes } \\
\text { aging skin } \\
\text { skin cancer }\end{array}$ \\
\hline Visible radiation & $\begin{array}{c}\text { Photoretinite } \\
\text { (photochemical } \\
\text { damage to the retina), } \\
\text { photothermal } \\
\text { damage to the retina }\end{array}$ & $\begin{array}{l}\text { Photosensitiv } \\
\text { e reactions }\end{array}$ \\
\hline $\begin{array}{l}\text { Near infrared radiation } \\
(700-1400 \mathrm{~nm})\end{array}$ & $\begin{array}{c}\text { Photothermal damage } \\
\text { to the retina, } \\
\text { cataract }\end{array}$ & $\begin{array}{l}\text { Photosensitiv } \\
\text { e reactions } \\
\text { inflammation } \\
\text { of the skin }\end{array}$ \\
\hline
\end{tabular}


О. С. Пітяков, Вип. 51, № 01, 2018.

\begin{tabular}{|l|c|c|}
\hline \multicolumn{1}{|c|}{ Spectrum range } & Eyes & Skin \\
\hline $\begin{array}{l}\text { Average infrared } \\
\text { radiation } \\
(1400-3000 \mathrm{~nm})\end{array}$ & $\begin{array}{c}\text { Cataract, } \\
\text { inflammation of the } \\
\text { cornea }\end{array}$ & $\begin{array}{c}\text { Inflammation } \\
\text { of the skin }\end{array}$ \\
\hline $\begin{array}{l}\text { Far infrared. } \\
\text { radiated } \\
(3000 \mathrm{~nm}-1 \mathrm{MM})\end{array}$ & Corneal inflammation & $\begin{array}{c}\text { Inflammation } \\
\text { of the skin }\end{array}$ \\
\hline
\end{tabular}

As you know, visual sensations arise due to photochemical reactions occurring in photosensitive cells which are sticks and cones. However, in addition to sticks and cones in the retina of the eye, there is another photoreceptor that are internal photosensitive ganglion cells. They do not perform the visual function, and together with melanopsin, which is receptor protein, transmit information about the level of illumination to the superhismatic nucleus, which control the release of the hormone melatonin from the pineal gland, and thus responds to the day and night rhythm.

Synthesis of melatonin begins at dusk and promotes sleep, morning light suppresses its formation. Thus, the reduction or increase in the level of melatonin is controlled by the amount of light that enters the eye. Melanospin is most sensitive in the blue region of the spectrum. This is evident from the dependence of its relative spectral sensitivity on the wavelength of optical radiation (Fig. 1). In this connection, the formation of melatonin is most depressed by a wavelength of $450-480 \mathrm{~nm}$, and the blue color becomes dangerous at night.

Not only melanopsin cells, but also sticks and cones influence the circadian rhythm. At the same time, cones are excited and begin to work under the influence of long-wave optical radiation, while melanospins cells are excited by short-wave radiation. After a certain period of radiation cones stop affecting the sleep, and melanopsin cells will be active throughout the duration of the radiation. Even people who have visual impairments whose sticks and cones do not work, circadian rhythms are not disturbed due to the action of retina melanopsin cells, which continue to respond to the level of ambient light and transmit information to the suprachasmatic nucleus. It regulates the circadian rhythm, daily fluctuations in the level of hormones, gene expression, body temperature, digestive activity, etc. [5].

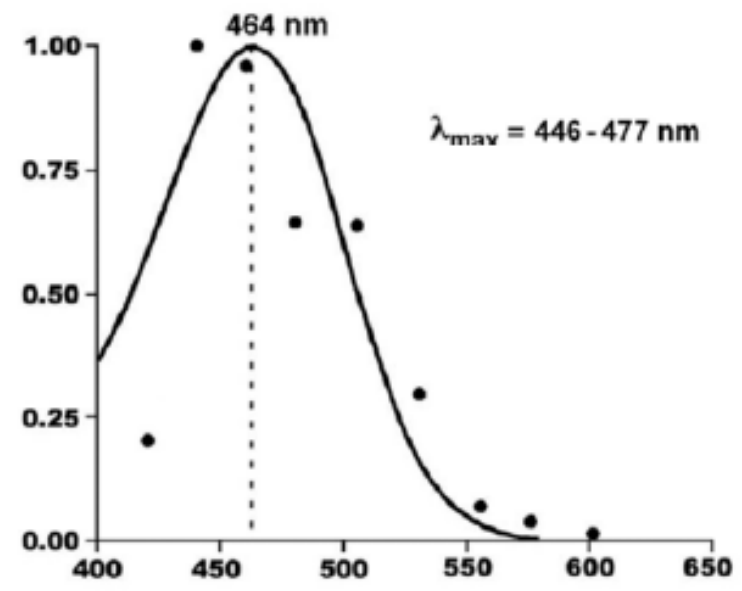

Fig. 1. Spectral sensitivity of melatonin perception
It has also been established that the retina of the eye becoming older has changes that can lead to disturbance of circadian rhythms. Therefore, deterioration of elderly people' vision can lead to chronic diseases. With age, the lens passes fewer rays of light, which leads to a decrease in the function of the suprachiosmatic nucleus. Therefore, the level of illumination for each age group of people plays an important role and acts on the body not only on the sensory level, but also on the hormonal, which in turn affects the general health of the organism.

As you know, solid-state light sources with a spectrum of radiation in the short-wave region (blue) are the most common. Therefore, taking into account photobiological effects on the body of blue light and the dangers associated with radiation of solid-state light sources, these studies are relevant and are widely discussed by scientists from various fields of science from different countries.

Parameters of photobiological safety of radiation of light sources. The determining factors for establishing the photobiological safety of a light source are the theory of risks and the methodology for quantifying the limits of exposure to hazardous blue light on the retina of the eye [6]. In this case, the limit values of photobiolecular safety indicators are calculated for the specified irradiation limits of the pupil diameter $-3 \mathrm{~mm}$ (pupil area $7 \mathrm{~mm} 2$ ). For these parameters of the pupil, the function $B(\lambda)$ was defined the spectral function of the danger of blue light (Fig. 2).

To assess the photobiological safety of light sources in the visible spectrum, the International Commission on Illumination CIE has implemented the standard IEC 62471 "Photobiological safety of lamps and lamp systems" $[4,7,8]$. According to this standard, light sources are divided into four groups:

Zero risk group (no risk). The effects of radiation from such light sources may occur after 10,000 seconds or more. These include: incandescent lamps, plasma and halogen lamps.

First risk group (low risk). The maximum exposure time is between 100 and 10,000 seconds. This group includes all types of lamps except incandescent lamps.

The second risk group (moderate risk). The maximum radiation exposure is possible in the range from 0.25 to 100 seconds. It also includes all types of lamps except incandescent lamps.

Third Risk Group (High Risk). The time of impact does not exceed 0.25 seconds. This group also includes all types of lamps except incandescent lamps.

The basic requirement of this standard is that people should not be irradiated from lamps and lamp systems to a level that exceeds the limits set by the standard. Also introduced is the concept of actinic dose - the magnitude obtained by the spectral assessment of the dose in accordance with the values of actinic action of a certain wavelength.

In Ukraine, on the basis of this standard, the standard DSTU IES 62471: 2009. The standard sets limits for exposures (GAEs), which should not be exceeded when using lamps and lamp systems in accordance with the above mentioned risk groups [7]. ГЗЕ are conditions under which it is supposed that almost every person can 
repeatedly be exposed to irradiation without irreversible consequences for health.

\section{REFERENCES}

[1] Sutter, E. (2008). Protection against optical radiation, VDE-Verlag, Berlin [in Deutsch].

[2] Recommendation of the German Commission on Radiological Protection (SSK): Glare from natural and new artificial light sources and their dangers (2006). Retrieved from http://www.ssk.de/SharedDocs/

Beratungsergebnisse_PDF/2006/Blendung_Lichtquellen.html. [in English].

[3] Okuno, T. (1991). Thermal effect of infra-red radiation on the eye A study based on a model, Ann. Occup. Hyg. 35, 1-12 [in English].

[4] Udovičić, L., Mainusch F., Janßen M., Nowack D., Ott G., (2013). Photobiological safety of light-emitting diodes (LED) Projekt F 2115 - the Federal Institute for Occupational Safety and Health, Dortmund/Berlin/Dresden. [in Deutsch].

[5] Citation: J. J. Gooley, S. M. W. Rajaratnam, G. C. Brainard, R. E. Kronauer, C. A. Czeisler, S. W. (2010). Lockley, Spectral responses of the human circadian system depend on the irradiance and duration of exposure to light. Sci. Transl. Med. 2, 31, 33 [in English].

[6] Sliney D.H., Lyon T.L. (2015). Optical Radiation Hazard Analysis. Retrieved from http://wildfirefx.com/resources/msds/WildfireUV_LED_SafetyStud y-VS-60.pdf. [in English].
[7] Kozhushko G.M. (2015). Schodo fotobiolohichnoi bezpechnosti svitlodiodnykh lamp ta svityl'nykiv [Concerning photobiological safety of LED lamps and fixtures] Promyslova elektroenerhetyka ta elektrotekhnika № 2., S. 26 - 33. [in Ukrainian].

[8] Pitiakov O. (2018). Fotobiolohichna diia svitlodiodiv ta problemy fotobiolohichnoi bezpeky ikh vyprominiuvannia [Photobiological effects of light-emitting diodes and problems of photobiological safety of their radiation] Materialy VI Mizhnarodnoi naukovotekhnichnoi konferentsii «Svitlotekhnika j elektroenerhetyka: istoriia, problemy, perspektyvy» (m. Ternopil' - m. Yaremche 30 sichnia - 2 liutoho 2018 r.) - Ternopil's'kyj natsional'nyj tekhnichnyj universytet im. I. Puliuia. S. 116 - 117. [in Ukrainian].

[9] Jordan V. (2009) Metrolohycheskye trebovanyia k opredelenyiu kharakterystyk fotobyolohycheskykh opasnostej lamp y svetodyodov [Metrological requirements for the determination of the characteristics of photobiological hazards of lamps and lightemitting diodes]. M.: Svetotekhnyka № 5, S. 50 - 57. [in Russian].

[10] Halbritter W., Horak W., Jordan W. (2008). Measurement requirements for the characterization of photobiological hazards posed by the optical radiation of lamps or LEDs, Proc. CIE Expert Symposium 2008 on Advances in Photometry and Colorimetry. [in English].

[11] Kaptsov V.A. Yzbytochnaia doza syneho sveta $v$ spektre svetodyodnoho osveschenyia mozhet ukhudshyt' zrenye [Excessive dose of blue light in the spectrum of LED lighting can impair vision] Enerhosvet: Elektronnyj zhurnal po enerhosberezhenyiu Retrieved from http://www.energosovet.ru/stat/ osv_875.pdf. [in Russian].

\title{
АНАЛІЗ ФОТОБІОЛОГІЧНИХ ПРОЦЕСІВ І ПОКАЗНИКІВ ФОТОБІОЛОГІЧНОЇ БЕЗПЕКИ ДЖЕРЕЛА ВИПРОМІНЮВАННЯ
}

\author{
О.С. Пітяков \\ Харківський національний університет міського господарства імені О. М. Бекетова \\ м. Харків, Україна
}

Встановлено, що фотобіологічні процеси, щуо виникають під впливом оптичного випромінювання, викликають фотохімічні та теплові реакиії в організмі. Такі реакиії безпосередньо пов'язані з поглинанням світла від природних і штучних джерел випромінювання. Встановлено, що глибина проникнення оптичного випромінювання залежить від довжини хвилі. Випромінювання "синього світла" найбільш небезпечно для шкідливого впливу на сітківку і вражає клітини меланопсина. Також у видимій області спектру штучних джерел світла, які використовуються тривалий час у вечірній і нічний періоди, може бути Небезпечний "зелене світло", так як він здатний порушувати циикадний ритм і створювати гормональний дисбаланс. Таким чином, тривала дія ультрафіолетового, видимого та інфрачервоного випромінювання на очі і шкіру може викликати мутацію генів, опіки, захворювання $і$ зміни циркадного ритму. У статті аналізуються і систематизуються можливі наслідки і пошкодження, які можуть виникнути в результаті такого впливу оптичного випромінювання.

Детермінантами встановлення фотобіологічної безпеки джерела світла є Теорія ризиків і методологія кількісної очінки меж впливу небезпечного синього світла на сітківку ока. Тому в статті також розглядається класифікація груп ризику для ламп і систем ламп. Стандарти визначають граничні значення опромінення-умови, при яких вважається, що практично кожна людина може піддаватися багаторазовому опроміненню без незворотних наслідків для здоров'я. Основна вимога стандартів полягає в тому, щчо люди не повинні піддаватися впливу ламп та систем освітлення понад меж, встановлених стандартом для груп ризику. Розглянута методика розрахунку енергетичної яскравості випромінювання джерел світла за різних умов спостереження $i$ максимально допустимого часу експозииї для визначення параметрів фотохімічного пошкодження ока. Для визначення параметрів можливого термічного пошкодження сітківки від випромінювання джерела світла розглянуто метод визначення енергетичної яскравості опікової небезпеки.

Ключові слова: оптичне випромінювання, фотобіологічна безпека, лампа, лампова система, експозиція. 


\title{
АНАЛИЗ ФОТОБИОЛОГИЧЕСКИХ ПРОЦЕССОВ И ПОКАЗАТЕЛЕЙ ФОТОБИОЛОГИЧЕСКОЙ БЕЗОПАСНОСТИ ИСТОЧНИКА ИЗЛУЧЕНИЯ
}

\author{
А.С. Питяков \\ Харьковский национальный университет городского хозяйства имени А. Н. Бекетова \\ г. Харьков, Украина
}

Установлено, что фотобиологические процессы, возникающие под воздействием оптического излучения, вызывают фотохимические и тепловые реакции в организме. Такие реакции напрямую связаны с поглощением света от естественных и искусственных источников излучения. Установлено, что глубина проникновения оптического излучения зависит от длины волны. Излучение "синего света" наиболее опасно для вредного воздействия на сетчатку и поражает клетки меланопсина. Также в видимой области спектра искусственных источников света, которые используются длительное время в вечерний и ночной периоды, может быть Опасный "зеленый свет", так как он способен нарушать ичиркадный ритм и создавать гормональный дисбаланс. Таким образом, длительное действие ультрафиолетового, видимого и инфракрасного излучения на глаза и кожу может вызвать мутацию генов, ожоги, заболевания и изменения циркадного ритма. В статье анализируются и систематизируются возможные последствия и повреждения, которые могут возникнуть в результате такого воздействия оптического излучения.

Детерминантами установления фотобиологической безопасности источника света являются теория рисков и методология количественной оченки пределов влияния опасного синего света на сетчатку глаза. Поэтому в статье также рассматривается классификация групп риска для ламп и систем ламп. Стандартьл определяют предельные значения облучения-условия, при которых считается, что практически каждый человек может подвергаться многократному облучению без необратимых последствий для здоровья. Основное требование стандартов заключается в том, что люди не должны подвергаться воздействию ламп и систем освещения сверх пределов, установленных стандартом для групп риска. Рассмотрена методика расчета энергетической яркости излучения источников света при различных условиях наблюдения и максимально допустимого времени экспозиции для определения параметров фотохимического повреждения глаза. Для определения параметров возможного термического повреждения сетчатки от излучения источника света рассмотрен метод определения энергетической яркости ожоговой опасности.

Ключевые слова: оптическое излучение, фотобиологическая безопасность, лампа, ламповая система, экспозиция... 